J. Dairy Sci. 92:3481-3483

doi:10.3168/jds.2009-2099

(c) American Dairy Science Association, 2009.

\title{
Short communication: Robertsonian translocations, chimerism, and aneuploidy in cattle
}

\author{
J. Citek, ${ }^{* 1}$ J. Rubes, $†$ and J. Hajkova† \\ *Department of Genetics, South Bohemia University, Studentska 13, CZ 37005 Ceske Budejovice, Czech Republic \\ †Veterinary Research Institute, Hudcova 70, CZ 32100 Brno, Czech Republic
}

\section{ABSTRACT}

The aim of this study was to evaluate frequencies of Robertsonian translocations, aneuploidy, and chimerism in Holstein-Friesian, Czech Simmental, and different beef breeds in the Czech Republic from 1996 to 2007. A total of 2,425 animals were examined: 2,377 males, (991 Holstein-Friesians, 1,218 Czech Simmental sires, 168 sires of beef breeds) and 48 females. Translocation was found in 10 Czech Simmental sires, 2 Highland, 1 Charolais, and 3 Blonde d' Aquitaine sires, and in 13 females. Chimerism (XX/XY) was found in 9 Czech Simmental sires, and in 5 Holstein-Friesian sires; XXX trisomy was found in 2 heifers and XXY trisomy in 3 Charolais sires. We recommend that animals with such anomalies should be disqualified from siring stock bulls.

Key words: cattle, aneuploidy, chimerism, translocation

Artificial insemination has revolutionized cattle breeding since it was first adopted several decades ago. However, the use of a small number of elite sires for AI presents considerable risks to cattle populations because of the possibility of the rapid spread of undiagnosed genetic defects and chromosomal abnormalities that, when in the form of certain translocations, have been reported to be harmful to fertility (Molteni et al., 2005; Bonnet-Garnier et al., 2008). Aneuploidies and chimerism can occur at a frequency of approximately $7 \%$, but Robertsonian translocations occur in $25 \%$ in beef cattle populations, and for this reason, cytogenetic surveys are applied (Nel et al., 1991; Seguin et al., 2000; Ducos et al., 2008). Chimerism is caused by the vascular connections between the placentas of developing twins of different sex. In heifers, this can cause freemartinism, which is the most frequent form of intersexuality in

Received February 3, 2009.

Accepted February 26, 2009.

${ }^{1}$ Corresponding author: citek@zf.jcu.cz cattle (Padula, 2005). Whether the fertility of chimeric males is affected is a more contentious issue; they have normal body conformation and external genitalia and some are fertile (Peretti et al., 2008). Cytogenetic analysis may also be applied to assess the biotoxic effects of environmental pollution (Rubes et al., 1997).

Recently, Ducos et al. (2008) published a survey of the cytogenetic screening of livestock populations in Europe. The Czech Republic was not included in the survey, even though cytogenetic testing of bulls has been conducted here since 1980. In this paper, we analyze the occurrence of translocations, aneuploidy, and chimerism in the Czech cattle population over the period from 1996 to 2007. Sires before admission to the AI programs and some elite heifers likely to mother breeding sires and females were tested.

Cytogenetic analyses of cultured lymphocytes were used to identify chromosomal abnormalities, as XX/ $\mathrm{XY}$ chimerism, aneuploidy, and chromosomal centric fusions can be detected using this method (McNiel et al., 2006). Recently, molecular methods have also been adopted (Vozdova et al., 2008). Here, conventional chromosome staining techniques were used. Giemsatrypsin GTG-banding analyses were carried out when abnormal chromosomes were identified.

From 1996 to 2007, a total of 2,425 animals were examined: 2,377 sires, and 48 females (Table 1). The male population examined consisted of 991 HolsteinFriesian sires, 1,218 Czech Simmental sires, and 168 sires of different beef breeds. The females were of an indiscriminate mixture of breeds, but most were Czech Simmental.

The XX/XY chimerism was found in 5 HolsteinFriesian sires and 9 Czech Simmental sires (Table 1) for a frequency of 0.50 and $0.74 \%$, respectively. This result is in close agreement with Slota et al. (2004), who found the rate of chimeric Polish Red sires to be $0.89 \%$. Nel et al. (1991) report a greater incidence of $1.85 \%$ in South African Friesian sires, and Seguin et al. (2000) an incidence of $0.99 \%$ in US Holstein-Friesian sires.

In testing for aneuploidies, 3 Charolais sires and 2 heifers were found to be carriers of a redundant sex 
Table 1. The number of animals in the survey and numbers found to have abnormal karyotypes

\begin{tabular}{|c|c|c|c|c|}
\hline Breed & Sex & $\begin{array}{c}\text { Total } \\
\text { surveyed, n }\end{array}$ & $\begin{array}{c}\text { Abnormal } \\
\text { karyotype, n (\%) }\end{array}$ & Karyotype \\
\hline Holstein-Friesian & Male & 991 & $5(0.50)$ & $60, \mathrm{XX} / 60, \mathrm{XY}$ \\
\hline Czech Simmental & Male & 1,218 & $\begin{array}{r}9(0.74) \\
10(0.82)\end{array}$ & $\begin{array}{l}60, \mathrm{XX} / 60, \mathrm{XY} \\
\text { rob t }(1 ; 29)\end{array}$ \\
\hline Beef & Male & 168 & $\begin{array}{l}3(1.79)^{1} \\
6(3.57)^{2}\end{array}$ & $\begin{array}{l}61, \mathrm{XXY} \\
\operatorname{rob} t(1 ; 29)\end{array}$ \\
\hline Indiscriminate & Female & 48 & $\begin{array}{c}2(4.17) \\
13(27.08)^{3}\end{array}$ & $\begin{array}{l}61, X X X \\
\text { rob t }(1 ; 29)\end{array}$ \\
\hline
\end{tabular}

chromosome (61,XXY and 61,XXX; Table 1). Autosomal aneuploidies were not found, although this does not exclude their occurrence. In the survey, only animals brought to full term were analyzed, so the level of abnormality found is likely to be an underestimate, assuming that serious chromosome abnormalities in the embryos of domestic animals are usually lethal and those embryos are eliminated during development (King, 2008). It is likely that cattle would show a trend similar to that in humans, in which $50 \%$ of spontaneous abortions at 8 to $16 \mathrm{wk}$ of gestation are due to cytogenetic causes (Byrne et al., 1985). In the group of animals in our analysis, autosomal aneuploidies were evidently lethal early in gestation, whereas the less harmful gonosomal aneuploidies allowed survival.

The search for Robertsonian translocations showed a relative frequency of $0.82 \%$ in Czech Simmental sires, $3.57 \%$ in beef sires (2 Highland, 1 Charolais, and 3 Blonde d'Aquitaine sires), and $27.08 \%$ in females (Table 1). The Holstein-Friesian sires and heifers examined were not affected. In females, the frequency was surprisingly high, but only those animals sired by translocation carriers were analyzed, rather than the total population as in males.

Our results are consistent with reports of other authors; for example, Seguin et al. (2000), who did not find any centric fusion in American Holstein-Friesian sires, but as indicated above, did find chimeric animals. Nel et al. (1991) note the lack of chromosomal aberrations in pure dairy breeds found by teams across the world, when the chimerism found in Holstein-Friesians cannot be considered a primary chromosome defect.

Because chimeric sires reportedly have decreased reproductive performance and the presence of Robertsonian translocations in dual-purpose and beef breeds has been confirmed, the early cytogenetic screening of sires before their admission to breeding programs seems to be advisable (Seguin et al., 2000). To prevent wide dispersion of these anomalies, affected animals should at least be disqualified from siring stock bulls. Of course, normal sires or dams of offspring with aneuploidy need not be culled, as the risk of recurrence of aneuploid fetuses is very low (Schmutz et al., 1996).

\section{ACKNOWLEDGMENTS}

Supported by the Czech Ministry of Agriculture (NAZV QF3012, MZE0002716202), and by the Ministry of Education (MSM6007665806).

\section{REFERENCES}

Bonnet-Garnier, A., S. Lacaze, J. F. Beckers, H. M. Berland, A. Pinton, M. Yerle, and A. Ducos. 2008. Meiotic segregation analysis in cows carrying the $\mathrm{t}(1 ; 29)$ Robertsonian translocation. Cytogenet. Genome Res. 120:91-96.

Byrne, J., D. Warburton, J. Kline, W. Blanc, and Z. Stein. 1985. Morphology of early fetal deaths and their chromosomal characteristics. Teratology 32:297-315.

Ducos, A., T. Revay, A. Kovacs, A. Hidas, A. Pinton, A. BonnetGarnier, L. Molteni, E. Slota, M. Switonski, M. V. Arruga, W. A. van Haeringen, I. Nicolae, R. Chaves, H. Guedes-Pinto, M. Anderson, and L. Iannuzzi. 2008. Cytogenetic screening of livestock populations in Europe: An overview. Cytogenet. Genome Res. 120:26-41.

King, W. A. 2008. Chromosome variation in the embryos of domestic animals. Cytogenet. Genome Res. 120:81-90.

McNiel, E. A., N. J. Madrill, A. E. Treeful, L. C. Buoen, and A. F. Weber. 2006. Comparison of cytogenetics and polymerase chain reaction based of the amelogenin gene polymorphism for the diagnosis of freemartinism in cattle. J. Vet. Diagn. Invest. 18:469-472.

Molteni, L., D. Meggiolaro, A. De Giovanni Macchi, L. De Lorenzi, P. Crepaldi, S. Stacchezzini, F. Cremonesi, and F. Ferrara. 2005. Fertility of cryoconserved sperm in three bulls with different Robertsonian translocations. Anim. Reprod. Sci. 86:27-36.

Nel, N. D., E. J. Harris, J. E. Weiermans, and E. H. H. Meyer. 1991. The cytogenetic screening of South African artificial insemination bulls. Genet. Sel. Evol. 23:109-117.

Padula, A. M. 2005. The freemartin syndrome: An update. Anim. Reprod. Sci. 87:93-109.

Peretti, V., F. Ciotola, S. Albarella, O. Paciello, C. Dario, V. Barbieri, and L. Iannuzzi. 2008. XX/XY Chimerism in cattle: Clinical and cytogenetic studies. Sex Dev. 2:24-30.

Rubes, J., Z. Pokorna, L. Borkovec, J. Urbanova, and V. Strnadova. 1997. Dairy cattle as a bioindicator of exposure to genotoxic substances in a heavily polluted area in Northern Bohemia. Mutat. Res. 391:57-70.

Schmutz, S. M., J. S. Moker, E. G. Clark, and J. P. Orr. 1996. Chromosomal aneuploidy associated with spontaneous abortions and neonatal losses in cattle. J. Vet. Diagn. Invest. 8:91-95. 
Seguin, B. E., T. Q. Zhang, L. C. Buoen, A. F. Weber, and G. R. Ruth. 2000. Cytogenetic survey of Holstein bulls at a commercial artificial insemination company to determine prevalence of bulls with centric fusion and chimeric anomalies. J. Am. Vet. Med. Assoc. 216:65-67.

Slota, E., A. Kozubska-Sobocinska, B. Danielak-Czech, B. Rejduch, P. Kowol, and A. Zyga. 2004. A note on cytogenetic monitoring of Polish Red cattle. J. Anim. Feed Sci. 1:65-71.
Vozdova, M., S. Kubickova, H. Cernohorska, and J. Rubes. 2008. Detection of translocation $\operatorname{rob}(1 ; 29)$ in bull sperm using a specific DNA probe. Cytogenet. Genome Res. 120:102-105. 